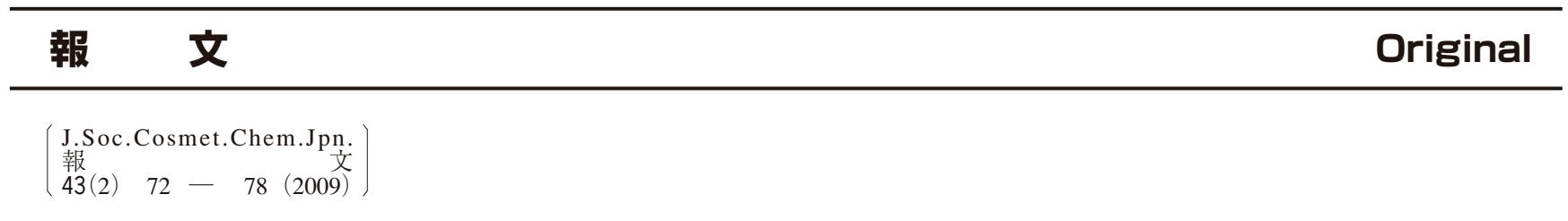

\title{
多重解像度解析を用いた肌のつやの 客観的評価方法と応用*
}

\section{藤 井 誠, 三㠃裕子, 佐々木一郎}

\author{
株式会社コーセー 研究所**
}

\begin{abstract}
肌のつやは, 物質としての皮膚の性質に加えて, 皮脂, 化粧膜, また皮膚表面の形状などの影響を うけ, 時には「てかり」と判断される場合があり, 光沢度が同程度でも光沢の質によっては, 望まし くない状態が存在する。そこで本研究では, 顔全体の光沢を一度に測定し, 目鼻立ちなどの顔の特徴 を表す光沢成分と，しわや毛穴などを表す光沢成分に分解する手法を開発した。これらの2つの成分 が与える光沢の印象の違いに着目し，この2つの光沢成分を定量化することで光沢の印象を表現し た。この手法では,まず二色反射モデルにもとづいて顔全体の光沢分布を画像として抽出した。次に， 多重解像度解析を行い, 毛穴やしわなどを表す光沢成分を texture image として, また, 顔の目鼻 立ちなどの特徵を表す成分は facial feature image として, 毛穴や鼻などの位置や形状を保存した まま，画像として抽出した。この手法によって，肌の光沢感をTexture Index (TI) と Facial Feature Index (FI) の2つのパラメータとして定量化し, 光沢の印象を定量化した。定義したパラメー タと官能評価による光沢の印象とを比較し, その信頼性を評価した結果, 提案した手法の有効性が示 唆された。
\end{abstract}

\section{1. 緒}

言

肌のつやは肌の美しさを表す重要な因子であるため, 肌につやを与えることは化粧品の重要な目的の一つであ る。光沢感のない肌は乾燥した印象を与え, その一方で, 過剩な光沢も良い印象を与えないため, 肌につや（適切 な光沢）を与える化粧品を開発するためには，まず光沢 が与える印象を客観的に評価することが不可欠である。

一般的な光沢の評価方法には，JIS で定められている 鏡面光沢度 ${ }^{1)}$ が広く用いられているが，人の顔のような 曲面物体には適さず，人間が知覚する光沢感 (心理光沢 度)とは必ずしも一致しないという久点がある21。また， 肌のつやは, 物質としての皮膚の性質に加えて, 皮脂, 化粧膜，また皮膚表面の形状などの影響をうけ，時には 「てかり」と判断される場合があり, 光沢度が同程度で も, 光沢の質によっては, 望ましくない状態が存在する。

*2007. 5. 11 受付, 2009.1.22 採用

** 个114-0005 東京都北区栄町 48-18:48-18 Sakae-cho, Kita-ku, Tokyo 114-0005, Japan
そのため, 肌のつやを評価するためには, 光沢を強度と して評価するのではなく, 光沢が顔全体に分布する様子 を評価する方法が必要である。

本研究では, この問題を解決するため, 顔全体を撮影 したデジタル画像を画像処理して光沢画像を推定する。 さらに目鼻立ちなどの顔の特徴を表す光沢成分と，しわ や毛穴などを表す光沢成分に分解する手法を開発する。 これらの 2 つ成分が与える光沢の印象の違いに着目 し，この 2 つ光沢成分を定量化することで光沢の印象 を表現し，スキンケア製片塗布直後の光沢の変化を評価 する。

\section{2. 実験}

\section{1. デジタル画像から鏡面反射光画像の推定}

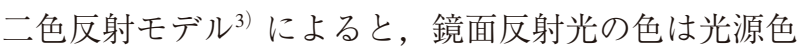
と同じ色であり，内部反射光の色は物体に固有の色にな るとされている。また，物体の反射光は鏡面反射光と内 部反射光の線形結合で表現できるため, デジタル画像 $(512 \times 512$ ピクセル，24bitRGB カラー）の各ピクセル の RGB カラーの色ベクトル $I(x, y) \quad(x, y$ はデジタル画 
像の座標) は, 各座標の肌色単位ベクトル $k_{B}(x, y)$ と, 光源色単位ベクトル $k_{S}$ を用いて, 式(1)のように表現さ れる。標準白色板を用いて光源色を直接測定することで $k_{S}$ を求め, 同時に撮影した偏光画像の值を用いて $k_{B}(x, y)$ を求めることで $K(x, y)$ が求められる。次に, $K(x, y)$ の Moor-Penrose 型一般逆行列 ${ }^{4)} K(x, y)+$ を計算することで,

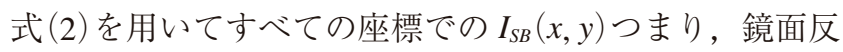
射光強度 $i_{S}(x, y)$ および, 内部反射光強度 $i_{B}(x, y)$ を求め ることができる。このとき, $i_{S}(x, y) k_{S}$ は鏡面反射光画像 を意味し,$i_{B}(x, y) k_{B}(x, y)$ は内部反射光画像を意味する。

$$
\begin{aligned}
& I(x, y)=i_{S}(x, y) k_{S}+i_{B}(x, y) k_{B}(x, y) \\
& =\left(i_{S}(x, y) i_{B}(x, y)\right)\left(\begin{array}{c}
k_{S} \\
k_{B}(x, y)
\end{array}\right) \\
& =I_{S B}(x, y) K(x, y) \\
& I_{S B}(x, y)=I(x, y) K(x, y)^{+}
\end{aligned}
$$

\section{2. 鏡面反射光画像の多重解像度解析}

分離した鏡面反射光画像は，顔の骨格や，肉付き，毛 穴や小じわといった表面形状や，表面に分布する皮脂の 影響をうけて肌の質感を表現している。鏡面反射光画像 は, 顔の骨格や肉付きなどを表す低解像度の成分と, 毛 穴や小じわなどを表す高解像度の成分が合成されたもの と考えられるので, 多重解像度解析 ${ }^{5)}$ によりこれらの成 分を分離することができる。そこで，われわれは Daubechies-4 を用いたWavelet 変換により，鏡面反射光 画像に多重解像度解析を行った。鏡面反射光画像を 9 つ の周波数帯域（Fig.-1）に分解 L, 高周波数側 (level 1４）号 texture imageを，低周波数側（level 5９） から facial feature image を再構成した（Fig.-2)。Texture image の分散を Texture Index (TI), facial feature image の分散を Facial Feature Index（FI）と定義し, 式(3)およ び式(4)で計算した。

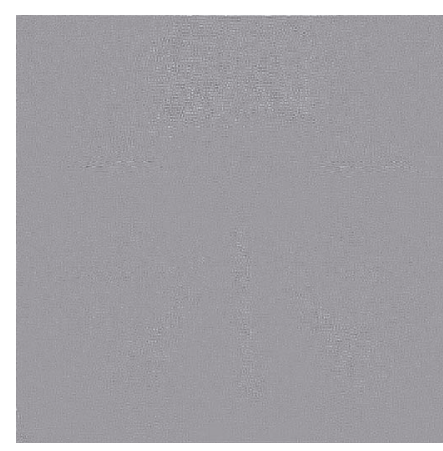

LEVEL 1

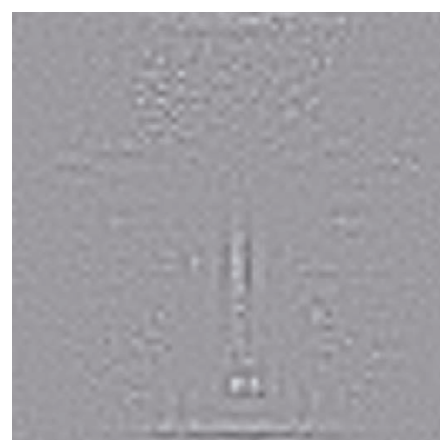

LEVEL 4

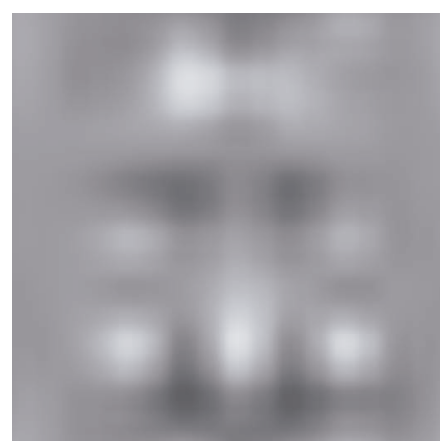

LEVEL 7

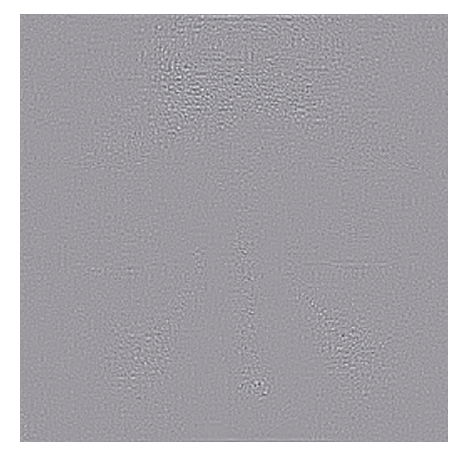

LEVEL 2

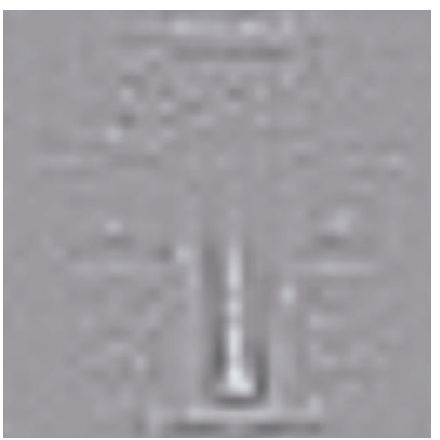

LEVEL 5

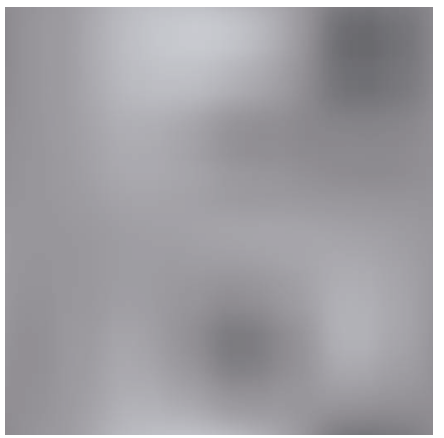

LEVEL 8

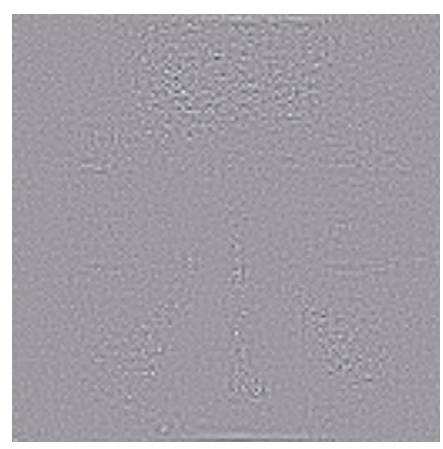

LEVEL 3

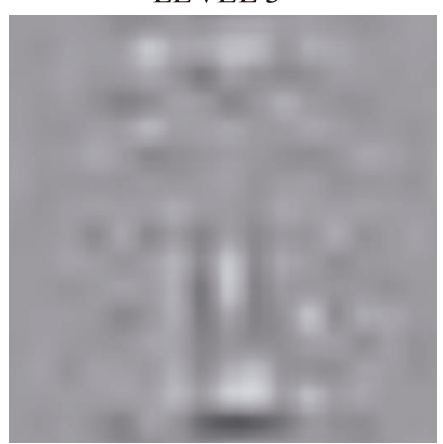

LEVEL 6

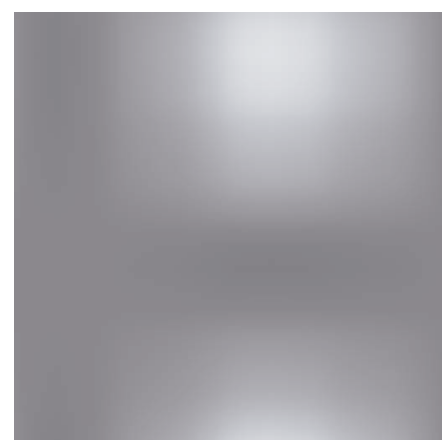

LEVEL 9

Fig.-1 Multi-Resolution Analysis of surface reflection image. 


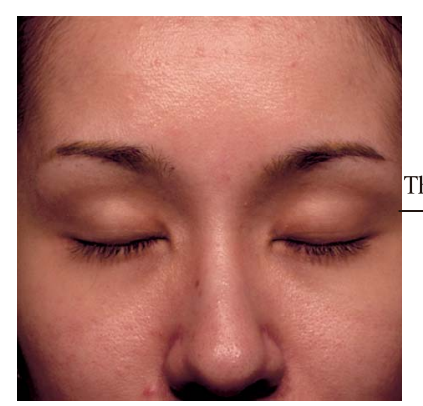

Original image

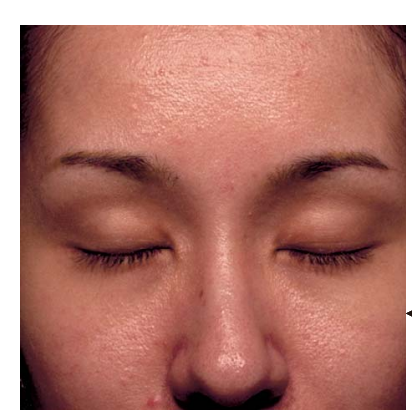

Synthesized image

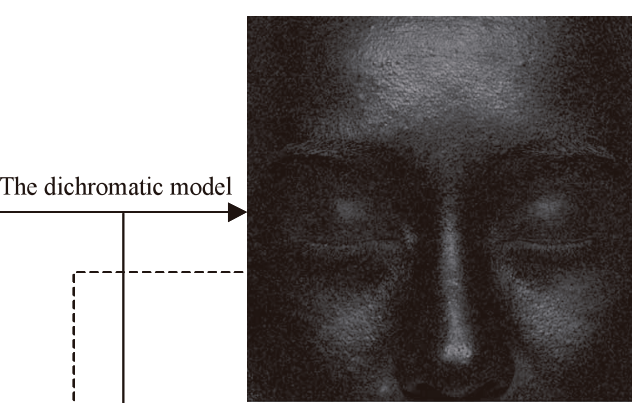

Surface reflection image

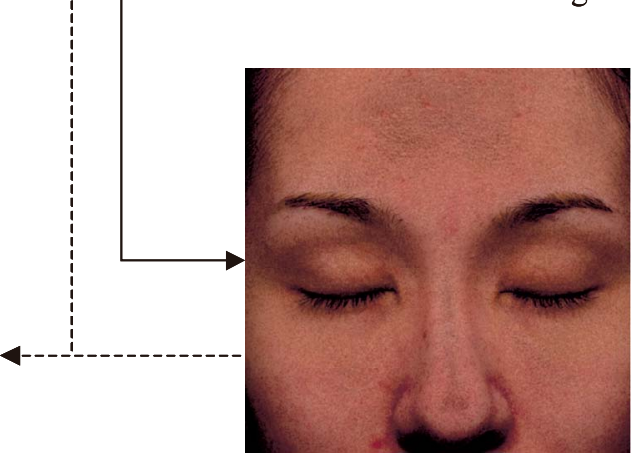

Body reflection image

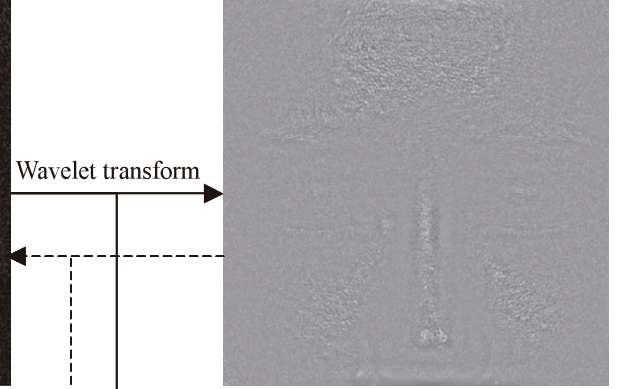

Skin texture image

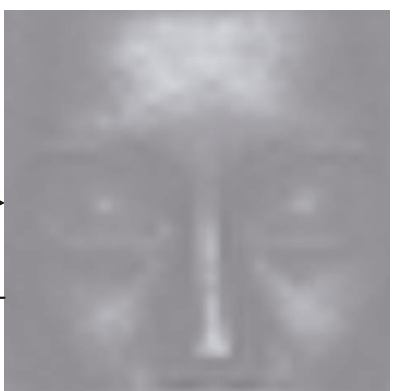

Facial feature image $\longrightarrow$ Decomposing $\longrightarrow$ Synthesizing

Fig.-2 Basic scheme of image analysis.

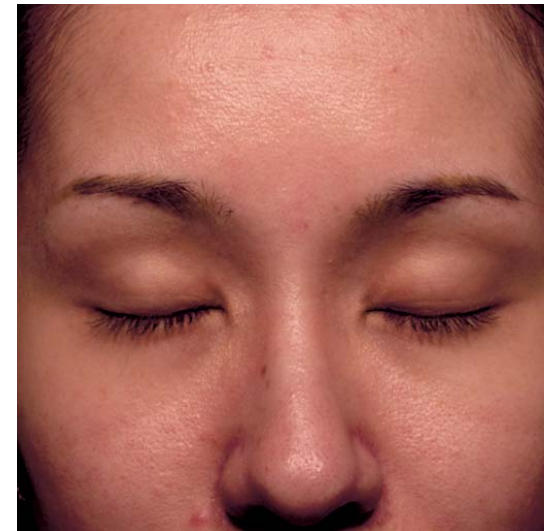

A. Original image $(\mathrm{TI}=56.2, \mathrm{FI}=253.8)$

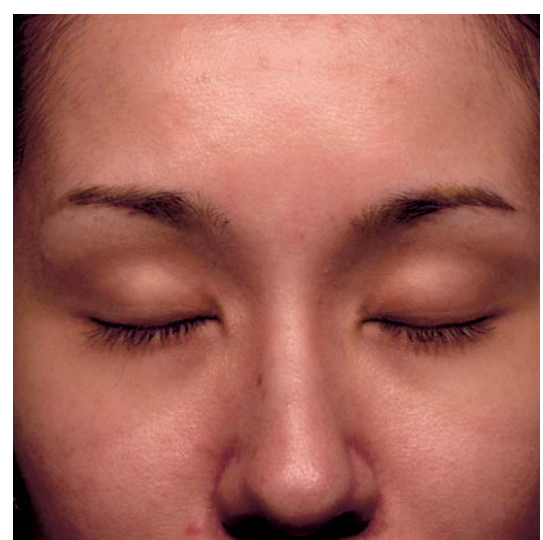

D. Synthesized image $(\mathrm{TI}=36.0, \mathrm{FI}=365.5)$

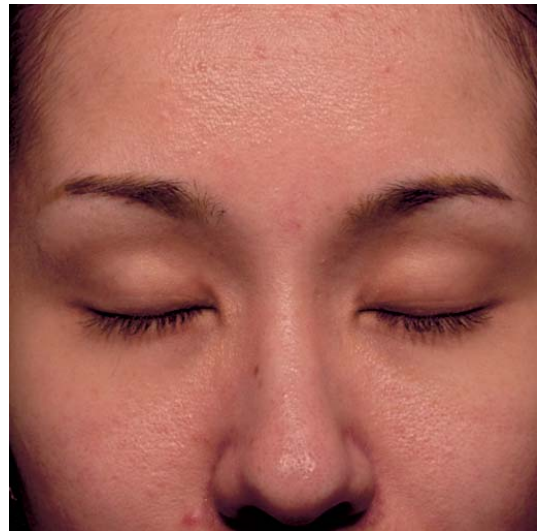

B. Synthesized image $(\mathrm{TI}=56.2, \mathrm{FI}=91.4)$

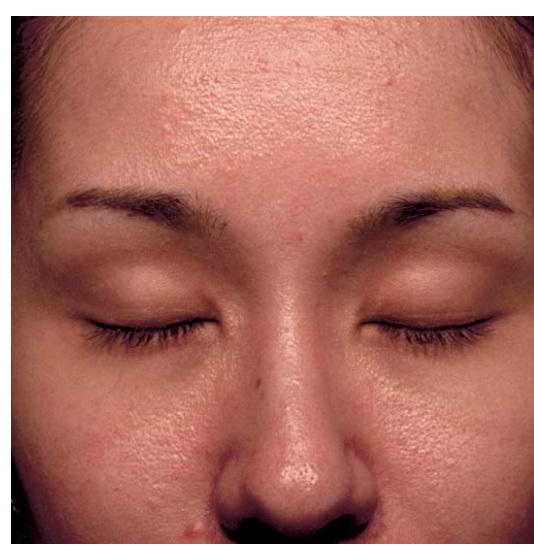

E. Synthesized image $(\mathrm{TI}=110.2, \mathrm{FI}=253.8)$

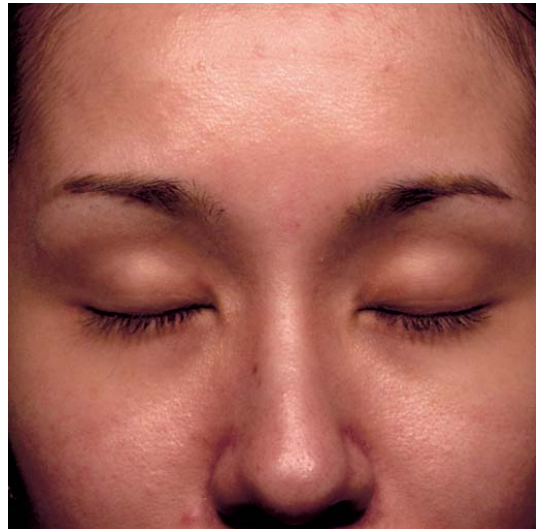

C. Synthesized image $(\mathrm{TI}=56.2, \mathrm{FI}=497.5)$

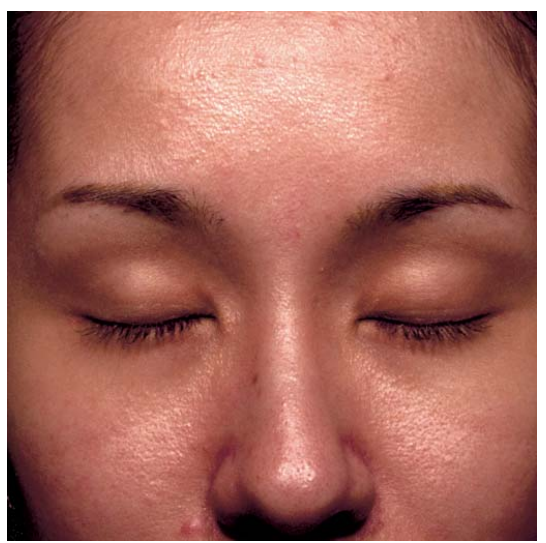

F. Synthesized image(TI=110.2, FI=497.5)

Fig. -3 Examples of synthesized images. 


$$
\begin{array}{r}
F I=\frac{\sum_{x} \sum_{y}(F(x, y)-\overline{F(x, y)})^{2}}{x y} \\
T I=\frac{\sum_{x} \sum_{y}(T(x, y)-\overline{T(x, y)})^{2}}{x y}
\end{array}
$$

\section{3. 鏡面反射光画像のシミュレーション および再構成}

分離した画像は original image に再構成することが可 能であり，また，再構成する前に texture image および facial feature image を強調, 減弱することで合成画像を 作製することができる。合成した画像を Fig.-3に示す。

\section{4. 光沢の測定}

光沢の測定は 17 人の健康な被験者 (男性 6 人, 女性 11 人，26〜 40 歳) に対して行った。撮影にはオリンパ ス社製 400 万画素のデジタルカメラを用いた。測定に当 たっては, 温度 $25^{\circ} \mathrm{C}$, 湿度 $50 \% \mathrm{RH}$ に設定された環境 試験室内で，セリック社製の $100 \mathrm{~W}$ の土太陽照明の もとで行った。

\section{5. 官 能 評価}

FI もしくは TI と光沢感の相関を調べるために, facial feature image および texture imageを強調減弱した合成画 像を作製した。オリジナル画像および，合成画像の FI およびTIの值を Table-1，2 に示した。光沢の強度と negative impression は官能評価による。官能評価は 20 名 の評価者に合成画像を一対比較法 ${ }^{6)}$ によって評価させ, 中屋の変法6)によって尺度化した。

\section{6. スキンケア製剤塗布前後の光沢の測定}

スキンケア製品使用前後の肌状態の変化が光沢感に与 える影響を調べた。被験者として 28 歳, TI = 60, FI $=210$ を示す女性を用いた。肌に残っている余分な皮脂 と角質の影響を除去するために, 測定の 30 分前に洗顔 を行った。水，1\%のスクワランを乳化したエマルショ ン，および $10 \%$ のスクワンを乳化したエマルション それぞれ $10 \mathrm{~g}$ をペーパーマスクに含浸させ，5分間顔面 に塗布した。光沢の測定は塗布後，0，30，60，120, 240 分後に行った。

\section{3. 結果および考察}

\section{1. 光沢の印象の官能評価と FI および $\mathrm{TI}$ の相関}

Fig. -4 と Fig. -5 に FI と TI と官能評価によって求めた 光沢の強度の相関を示した。FI と TI はともに, 光沢の 強度と高い相関があることがわかった。また, Fig. -6 と Fig.-7にFI と TI と negative impressionの相関を示した。
Table-1 FI and TI values of synthesized images prepared for visual evaluation of gloss intensity.

\begin{tabular}{crc}
\hline & TI & FI \\
\hline No.1 & 20.24 & 253.84 \\
No.2 & 35.98 & 253.84 \\
No.3 & 56.22 & 253.84 \\
No.4 & 80.95 & 253.84 \\
No.5 & 110.19 & 253.84 \\
No.6 & 56.22 & 91.38 \\
No.7 & 56.22 & 162.46 \\
No.8 & 56.22 & 253.84 \\
No.9 & 56.22 & 365.54 \\
No.10 & 56.22 & 497.53 \\
\hline
\end{tabular}

Table-2 FI and TI values of synthesized images prepared for visual evaluation of negative impressions.

\begin{tabular}{ccc}
\hline & TI & FI \\
\hline No.11 & 35.98 & 162.46 \\
No.12 & 56.22 & 162.46 \\
No.13 & 80.95 & 162.46 \\
No.14 & 35.98 & 253.84 \\
No.15 & 56.22 & 253.84 \\
No.16 & 80.95 & 253.84 \\
No.17 & 35.98 & 365.54 \\
No.18 & 56.22 & 365.54 \\
No.19 & 80.95 & 365.54 \\
\hline
\end{tabular}

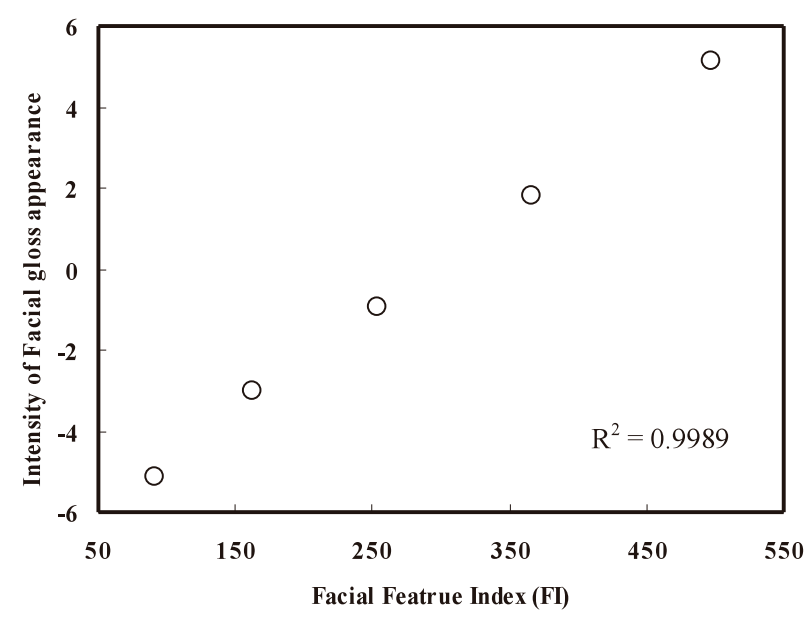

Fig. -4 Correlation between visual facial gloss intensity of synthesized images and Facial Feature Index (FI). Facial gloss intensities of images (No.6 to No.10 listed in Table -1 ) were obtained from the scores of visual evaluation. 
TI は negative impression とも強い相関があったが, FI と negative impression との間には相関は認められなかった。

TI は肌の微細形状，たとえば，毛穴や，ニキビ，し わなどの影響を受けた光沢感を表している。そのため, TI の值が高いと肌の微細形状が強調され, オイリーな 印象（以下，oily-look）を与えるため (Fig.-3E, F), negative impressionの值が高くなると考えられる。一方, TI が低いと肌の微細形状が目立たなく見えるため, 望 ましい光沢感（以下， radiant）を示すと考えられる。つ まり，TI は光沢が与える印象に大きな影響を与える指 標であることがわかる。逆に, FI は顔の特徴である鼻

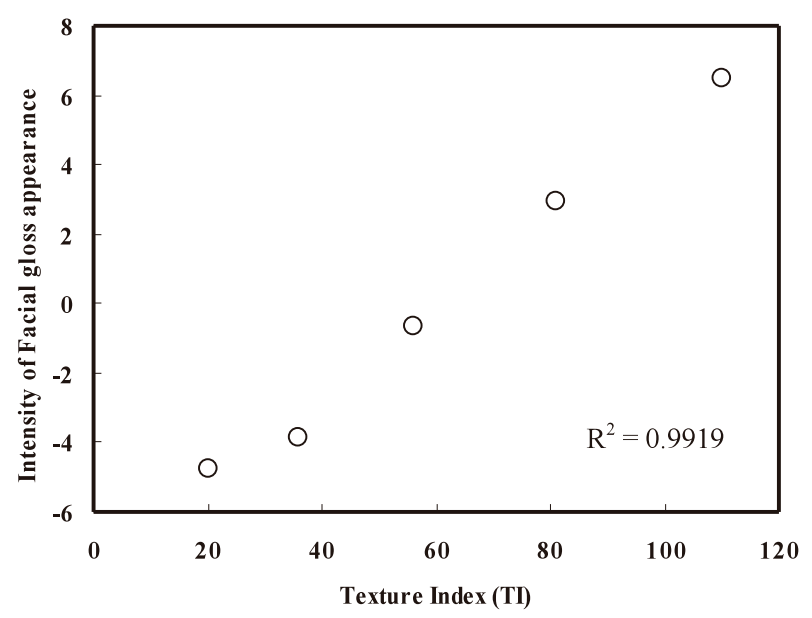

Fig.-5 Correlation between visual facial gloss intensity of synthesized images and Texture Index (TI). Facial gloss intensities of images (No.1 to No.5 listed in Table-1) were obtained from the scores of visual evaluation.

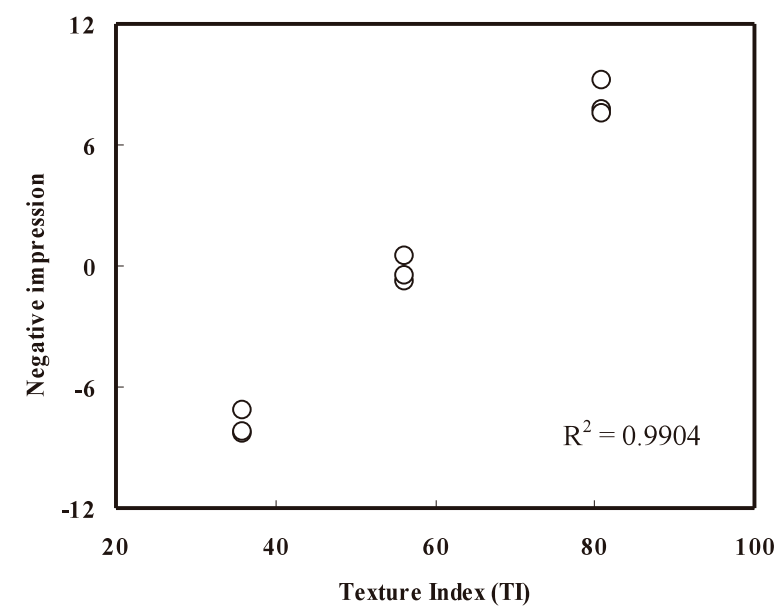

Fig.-6 Correlation between negative impression of synthesized images and Texture Index (TI). Negative impressions of images (No.11 to No.19 listed in Table-2) were obtained from the scores of visual evaluation.
や㚘骨や額などの影響を受けた光沢を表しており，光沢 から感じる印象に影響を与えない, 純粋な光沢の強さの 指標であることがわかる。

\subsection{FI および TI を用いた光沢のマッピング}

FI-TI 平面上の位置は光沢感を示している。FI-TI マッ プ（Fig.-8）から，テストした被験者は大きく 2 かのグ ループに分類できた。TIの值が 40～60 を示す光沢は radiant, 70〜100 の值を示す光沢は oily-look と評価され た。TIが60〜 70はどちらとも判断がつきにくい光沢で あった。この結果は合成画像の官能評価の結果（Fig.-6） とも一致している。FIが300〜400, TI は低い值（特に

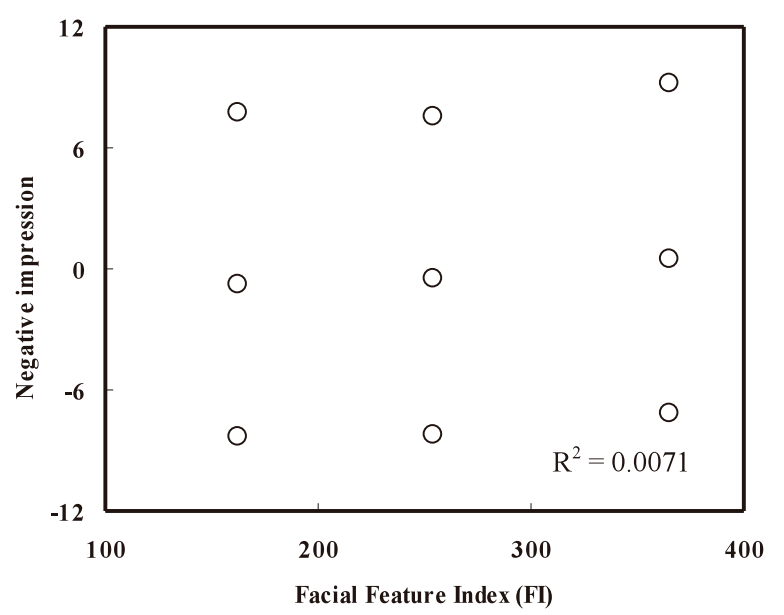

Fig. -7 Correlation between negative impression of synthesized image and Facial Feature Index (FI). Negative impressions of images (No.1 to No.10 listed in Table-1) were obtained from the scores of visual evaluation.

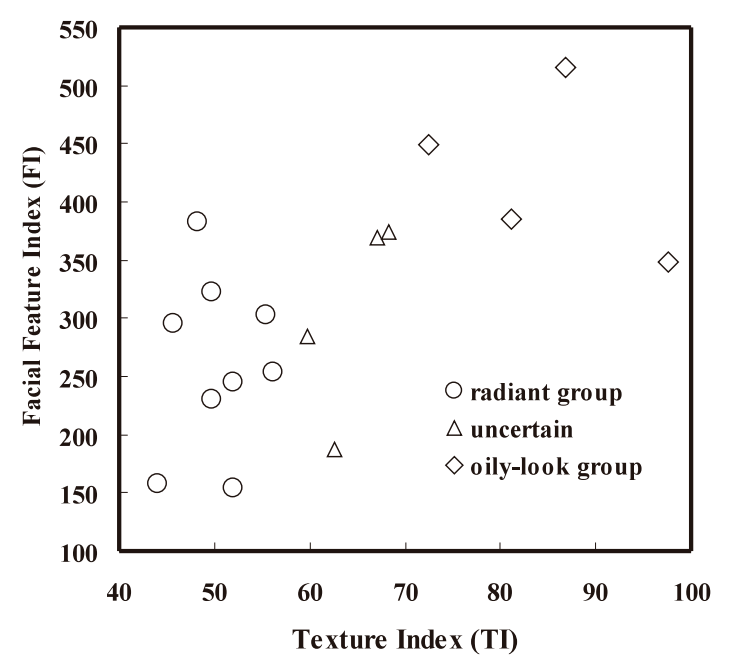

Fig.-8 FI-TI mapping of 17 subjects facial gloss appearance. 


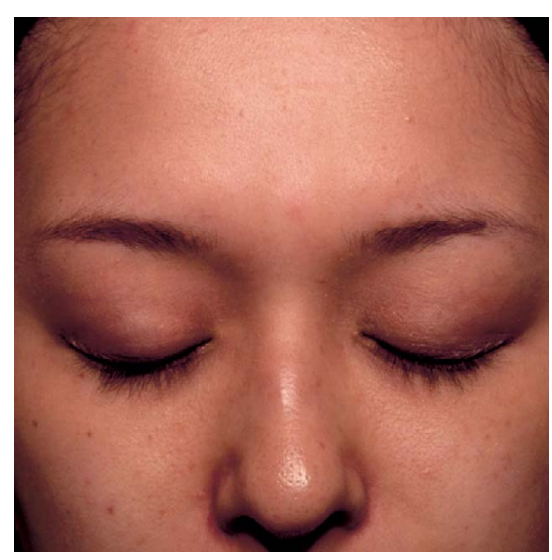

A. Example of radiant group

$(\mathrm{TI}=49.7, \mathrm{FI}=322.9)$

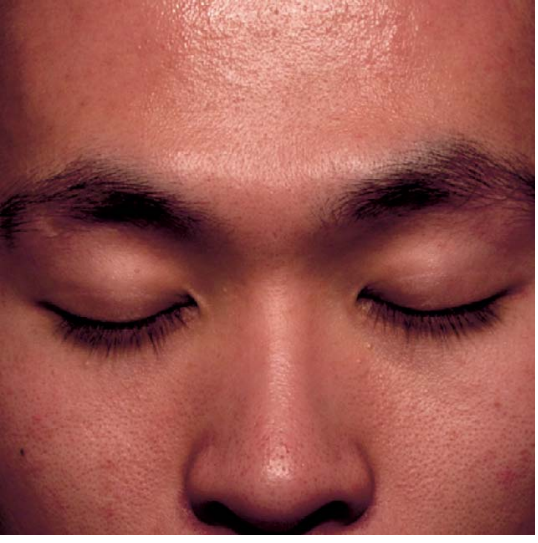

B. Example of oily-look group

$(\mathrm{TI}=97.7, \mathrm{FI}=348.1)$

Fig.-9 Examples of the images.

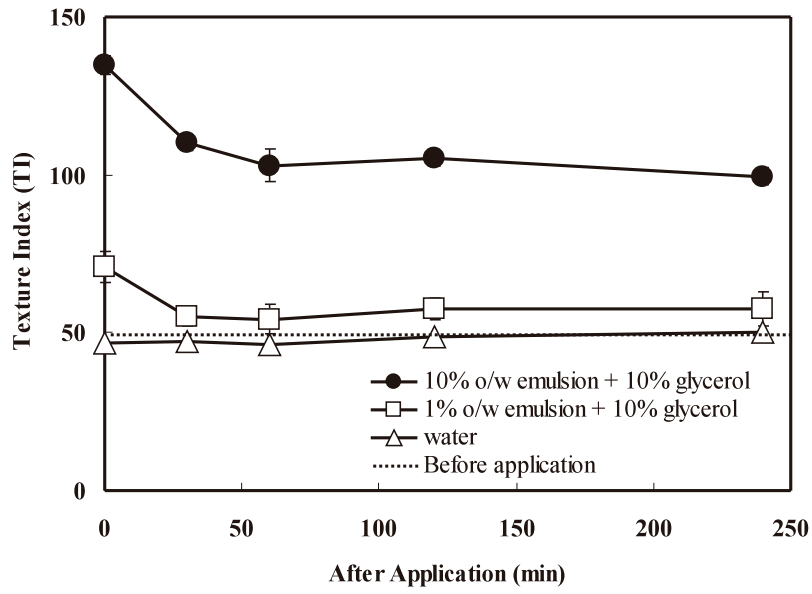

Fig.-10 Changes in the Texture Index of the face treated with various formulations.

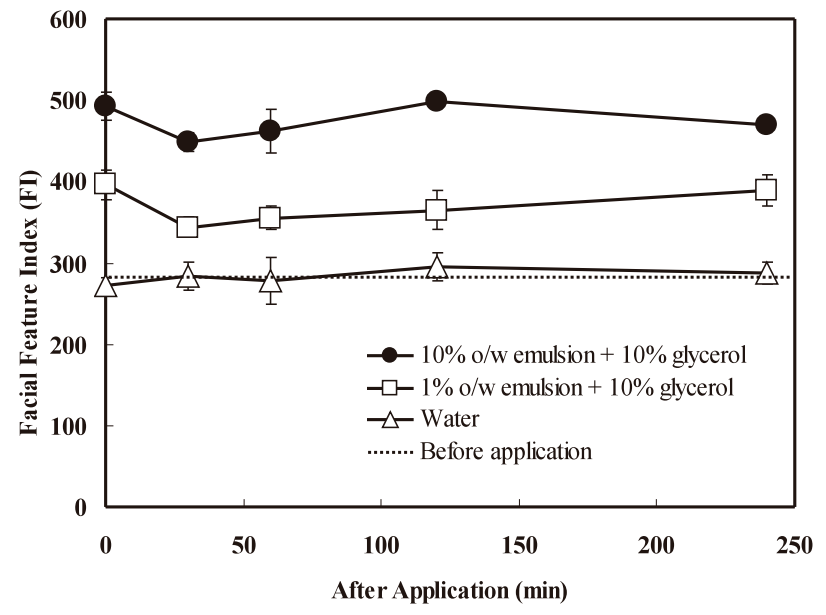

Fig. -11 Changes in the Facial Feature Index of the face treated with various formulations.

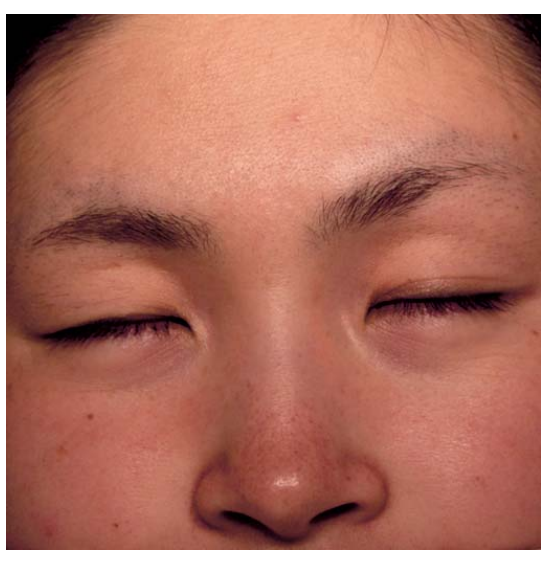

A. Before application

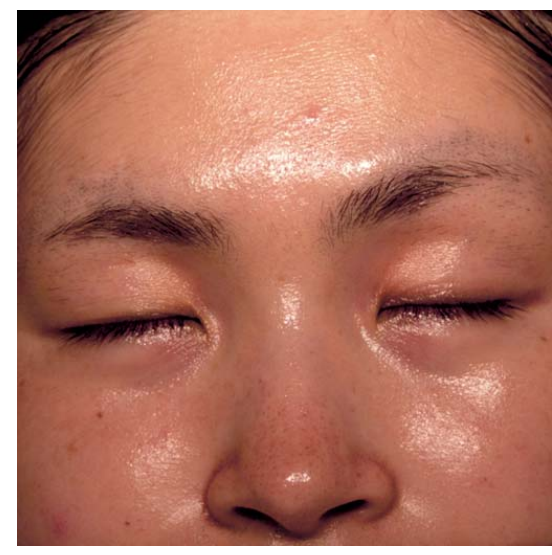

B. Immediately after application of the $10 \% \mathrm{O} / \mathrm{W}$ emulsion

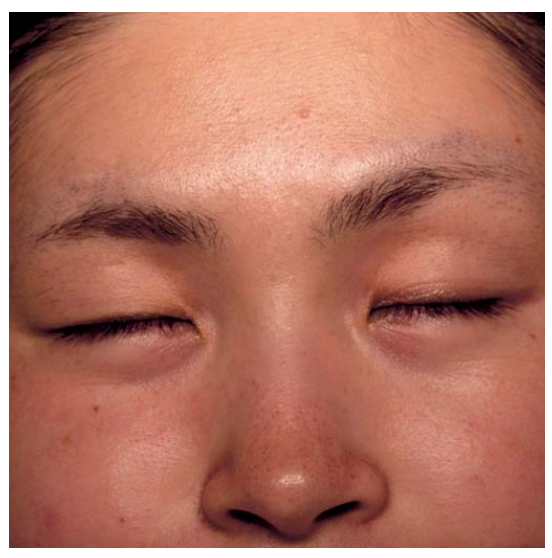

C. 240 minutes after application of the $1 \% \mathrm{O} / \mathrm{W}$ emulsion

Fig. -12 Changes gloss appearance before and after application of the $1 \%$ and $10 \% \mathrm{O} / \mathrm{W}$ emulsion. 
50 以下）を示すほうが理想的な光沢感を示した。Radiant および oily-look と評価された一例を Fig.-9に示す。Fig.9A は TI=49.7, Fig.-9B は TI=97.7である。実際の写 真からも, これら 2 つ光沢感には顕著な差を確認する ことができる。

\section{3. スキンケア製㓮による光沢の最適化}

水を塗布した場合には，使用前後において FI，TIに 顕著な差がみられなかった（Fig.-10，11）ことから， 水のみでは光沢感に変化を与えることができないことが わかった。 $1 \%$ および $10 \%$ エマルションを塗布した直後 は, いずれの場合も FI および TI の值は増加した。実際 に光沢感も oily-look であった(Fig.-12B)。1\%エマルショ ン塗布の場合には, 30 分後には TI の值はエマルション を塗布する前と同程度まで減少し, 光沢感も oily-look から radiantへと変化した。また, FI は塗布前に比べて 高い值を維持しており，この効果は 240 分後まで持続し ていた。一方，10\%エマルション塗布では，FIおよ゙ TI ともに2 40 分後まで高い值を示し, 光沢感は oilylookのままであった。この結果から，1\%エマルション の塗布により, 今回の被験者には肌に適切な光沢を与え られることがわかった。

\section{4. 結}

論

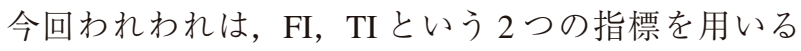
ことで肌上における光沢の分布を定量的かつ正確に評価 する手法を開発した。この手法を用いて光沢を評価した 結果，FIが300〜400，TI は低いほど（特に50以下） 理想的な光沢であることがわかった。この手法を応用す ることで, 肌に適切な光沢感を与える商品のみならず, 健康的な肌へ導くためのより効果的な商品の開発が期待 される。

\section{引用文献}

1）日本工業標準調査会, JIS Z 8741 日本規格協会（1983）

2）芹沢聖一, 下村輝夫, 応用物理, 66, 1067-1072（1997）

3) S. A. Shafer, Color Res. Appl., 10, 210-218 (1985)

4) 岡本良夫, 武者利光監修, 逆問題とその解き方, オー ム社, 1992, p.127-131

5) 新島耕一, ウェーブレット画像解析, 科学技術出版, 1999, p.55-63

6）官能検査ハンドブック，日科技連官能検査委員会, 1973, p.349-393

\title{
Application of Image Processing Technique for Facial Gloss Evaluation *
}

\author{
Makoto Fujii, Yuko Misaki, Ichiro Sasaki \\ Research Laboratories KOSE Corporation **
}

\begin{abstract}
A total absence of gloss can make the skin appear dry, while excessive gloss can contribute to an unattractive, "oily-look." Traditionally, skin gloss has been measured by the intensity of surface reflection. The disadvantage of this method is that the gloss is determined by the amount of the surface reflection in small, localized facial areas only, and does not permit evaluation of the overall optical impression of the entire face. In our work, we recognized differences in the optical contribution of facial features such as the nose and cheekbones, and surface characteristics such as pores and wrinkles. Highlights from facial features are usually regarded as normal whereas the highlight from skin texture can accentuate the presence of large pores and wrinkles, contributing to a negative impression. For an accurate evaluation of facial gloss impression, these contributions were taken into consideration in designing our system. In this study, we propose a new method of evaluating facial gloss using an image processing technique. By this method, the surface reflection image is computed from the digital color image, and separated into the facial feature and texture images for quantitative evaluation. The purpose of this work is to explore the possibility of using 2-dimensional parameters of gross appearance in our system for more accurate and objective evaluation of gloss impression.
\end{abstract}

Key words : wavelet, facial gloss, simulation, oily-look, radiant, surface reflection, facial feature image, texture image, highlights 